\title{
International Journal of Traditional and Complementary Medicine
}

(ISSN: 2474-1361)

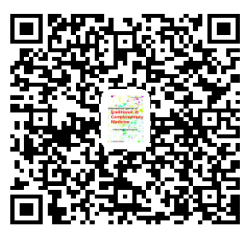

\section{COMPUTATIONAL STUDIES OF DUSPARSAKADI KWATHA AN AYURVEDIC}

\section{CLASSICAL MEDICINE FOR HEMORRHOIDS}

\section{Abhilash Mullasseril}

Mullasseril, Veliyanad POST., Ernakulam DIST., Kerala-682 313. INDIA

\section{ABSTRACT}

There are many methods to theoretically compute the efficacies of modern medicaments. These methodologies are not suitable for computing the efficacies of formulations used in Alternative Systems of Medicines especially to Ayurvedic formulations. In this paper a computational method developed earlier for computing the Drug Efficacy Indices of Ayurvedic formulations was applied to Dusparsakadi Kwatha a formulation for treating Hemorrhoids. The primary study objective of this research is to compute and compare the Drug Efficacy Indices of various possible combinations mentioned in the Classical Texts for treating Hemorrhoids and marketed by modern manufactures under the name Dusparsakadi Kwatha. The linguistic analysis of the corresponding verse of the classical formulation was done using the language interpretation methods based on Paninian concepts. The Drug Efficacy Indices were computed using the earlier reported formula. It is not a clinical study and purely theoretical methods based on the philosophical background of Ayurveda are applied. The computed Drug Efficacy Indices of some of the possible combinations were found more than the marketed formulation. These combinations were successfully practiced by many learned traditional practitioners by adhering to the meaning of the verses of classical texts. The studies successfully computed the efficacies of various combinations. It also showed that the research methodologies must be based on the philosophical background of Alternative Systems of Medicine alone can be successfully applied to their fields.

Key words: Efficacy, Drug Efficacy Index[Q(VPK)], Dusparsakadi Kwatha, Hemorrhoids, Arsoroga
*Correspondence to Author: Dr Abhilash Mullasseril Mullasseril, Veliyanad POST., Ernakulam DIST., Kerala-682 313. INDIA.

Email: mabhilash @ hotmail.com

How to cite this article:

Abhilash Mullasseril. COMPUTATIONAL STUDIES OF DUSPARSAKADI KWATHA AN AYURVEDIC CLASSICAL MEDICINE FOR HEMORRHOIDS. International Journal of Traditional and Complementary Medicine 2016; 1(2): 00240032.

Published September 292016.

eSciencePublisher eSciPub LLC, Houston, TX USA. Website: http://escipub.com/ 
Table 1: The Drug Efficacy Indices $\left[\mathrm{Q}_{(\mathrm{VPK})}\right]$ of Dusparsakadi Kwatha and its individual constituents.

\begin{tabular}{|c|c|c|c|c|c|c|c|}
\hline $\begin{array}{l}\text { S I. } \\
\text { No. }\end{array}$ & Content & Ratio & Qv & Qp & Qk & $\mathbf{Q}_{(\mathrm{VPK})}$ & $\begin{array}{l}\text { Pharmacological Type and Proper- } \\
\text { ties }\end{array}$ \\
\hline 1 & $\begin{array}{l}\text { Dusparsakadi } \\
\text { Kwatha } \\
(\mathrm{I}, \mathrm{II}, \mathrm{III}, \mathrm{IV} \& \mathrm{~V})\end{array}$ & 1:1:1:1:4 & 22.67 & -17.39 & -59.94 & 0.55 & $\begin{array}{l}\text { Pitta-Kaphaghni } \\
\text { Rasa : Tikta (69\%) Katu (25\%) } \\
\text { Veerya: Ushna (88\%) } \\
\text { Vipaka : Katu (88\%) }\end{array}$ \\
\hline 2 & Dusparsa(I) & 1 & 42.42 & -45.45 & -12.12 & 0.15 & $\begin{array}{l}\text { Kapha-Pittaghni } \\
\text { Rasa :Tikta }(85 \%), \text { Katu (10\%) } \\
\text { Veerya }\end{array}$ \\
\hline 3 & Vilwa(II) & 1 & 18.75 & -20.83 & -60.42 & 0.63 & $\begin{array}{l}\text { Pitta-Kaphaghni } \\
\text { Rasa : Tikta }(85 \%) \text { Kashaya }(10 \%) \\
\text { Veerya: Ushna }(100 \%) \\
\text { Vipaka : Katu }(100 \%)\end{array}$ \\
\hline 4 & Yavani(III) & 1 & 20.00 & 20.00 & -60.00 & 0.20 & $\begin{array}{l}\text { Kaphaghni } \\
\text { Rasa : Katu }(100 \%) \\
\text { Veerya: Ushna }(100 \%) \\
\text { Vipaka : Katu }(100 \%)\end{array}$ \\
\hline 5 & Nagara(IV) & 1 & -33.33 & 33.33 & -33.33 & 0.33 & $\begin{array}{l}\text { Vata-Kaphaghni } \\
\text { Rasa : Katu (100\%) } \\
\text { Veerya: Ushna }(100 \%) \\
\text { Vipaka : Swadu }(100 \%)\end{array}$ \\
\hline 6 & Patha(V) & 1 & 19.15 & -19.15 & -61.70 & 0.62 & $\begin{array}{l}\text { Pitta-Kaphaghni } \\
\text { Rasa:Tikta }(95 \%) \\
\text { Veerya:Ushna }(100 \%) \\
\text { Vipaka:Katu }(100 \%)\end{array}$ \\
\hline
\end{tabular}




\section{INTRODUCTION}

The contributions of the great ancient Indian Rishis or scientists to the field of Alternative Medicines are very precious and even found effective for managing various diseases in the modern era of medical sciences. In various ancient texts or Samhitas our forefathers explained their findings poetically in the scientific language Sanskrit very wisely for the benefit of the entire world. The modern scientists, researchers and even Ayurveda practitioners wonder how they arrived to these findings in those ancient days of primitive knowledge (?) with limited research facilities (?). The more I read and interrogate the subject matter the more I wonder and believe in their divine capabilities that lead to their findings ${ }^{1}$. We can even find the most advanced concepts comparable with modern concepts that are helpful in the research fields such as drug designing and drug discovery ${ }^{2}$. We wonder on the well claimed pharmacological activities attributed to those yogas or formulations and some of us believe and others don't on those claims merely because of the lack of well studied clinical evidences. Some of the modern researchers are working on those claims by merely applying modern methodologies suited for modern medicine research. But when we read through their reported clinical findings we can observe the limitations of those modern methodologies when applied as such to the field of Ayurveda research. The modern scientists believe that the active ingredients or active principles present in the drug used for the yogas or formulations are the root cause for their shown clinical activities. They also believe that the synthetic chemical equivalents of those active ingredients could be the best substituent for those herbs. But remember in Samhitas the ancient Rishis(Scientists) had mentioned different Pratinidhi dravyas for different situations instead of the main herb that may be entirely different in their active chemical ingredients. Even there might be numerous unrevealed chemical constituents present in these herbs that are yet to be clinically studied. It is worthwhile to recall a part of sloka attributed to Krishna the supreme lord to Arjuna viz. "Swalpamapyasya Dharmasya Trayate Mahato Bhayat" in Bhagavat Gita ${ }^{3}$. Similarly those unrevealed chemical constituents or revealed but not considered as the main constituents due to small quantities might be the real attributers for the clinical activities. The methodologies accepted for the modern clinical researches for calculating the efficacies of drugs cannot be adopted for Ayurveda researches for many reasons. The prime reason is that those methodologies were developed based on modern scientific knowledge only for the modern drug research. The branches of alternative medicines like Ayurveda has a unique philosophy and the methodologies developed based on the very same alone has to be adopted for research applications. Here in this research paper a unique computational method developed based on the classical principles of Ayurveda alone is to be used to calculate theoretically the efficacies of various combinations explained in ancient texts.

Hemorrhoids- Ayurvedic concept: It is a varicose condition of the hemorrhoidal veins causing painful swellings at the anal canal. In ancient literature the Hemorrhoids or Arsaoroga are explained in various Samhitas. According to Madhavakara there are six types of hemorrhoids viz. due to the vitiation of single doshas (3types), due to the combined vitiation of all the doshas (1type), due to the vitiation of Rakta dhatu (1type) and Sahaja (1type) ${ }^{4}$. There are possibilities for the types due to the vitiation of two doshas and one another type due to the vitiation of all the three doshas. According to Caraka hemorrhoids or arsas is the vikara of mamsadhatu and its deficiency in the hemorrhoidal veins lead to sirasaithilya resulting aneurysms of hemorrhoidal veins. The piles or hemorrhoids may be internal or external based on their origin. The modern medical science classify piles those arise in the upper anal canal and lower rectum from the internal venous hemorrhoidal plexus to internal piles and those arise in the skin lined lower anal canal due to the enlargement of external hemorrhoidal pluxes to external piles. In addition they also classify the piles to non-bleeding and bleeding piles. Similarly Caraka clinically classify piles or arsas in to two varieties viz. Ardra and Suska. The piles that bleeds or 'make wet' which is a common sign of internal piles is known as Ardra arsas and the piles that 'seem to dry' which is a common sign of external piles as Suska arsas. According to Susruta the arsas is due to the combined vitiation of two doshas and surgery is preferred for curing. Based on the tridosha concept the internal hemorrhoids or 
Table 2: The Drug Efficacy Indices $\left[\mathrm{Q}_{\mathrm{(VPK}}\right]$ of combinations in which individual constituent was mixed in a ratio (1:2) with patha.

\begin{tabular}{|c|c|c|c|c|c|c|c|}
\hline SI. No. & $\begin{array}{l}C \circ n- \\
\text { tent }\end{array}$ & Ratio & Qv & Qp & Qk & $\mathbf{Q}_{(\mathrm{VPK})}$ & Pharmacological Type and Properties \\
\hline \multirow[t]{4}{*}{7} & I \& V & $1: 2$ & 28.75 & -30.00 & -41.25 & 0.43 & Pitta-Kaphaghni \\
\hline & & & & & & & Rasa $\quad$ :Tikta (92\%) \\
\hline & & & & & & & Veerya : Ushna (67\%) \\
\hline & & & & & & & Vipaka :Katu (100\%) \\
\hline
\end{tabular}

$8 \quad$ II\&V $\quad 1: 2 \quad 19.01 \quad-19.72 \quad-61.27 \quad 0.62$

\section{Pitta-Kaphaghni}

Rasa:Tikta (92\%)

Veerya:Ushna (100\%)

Vipaka:Katu (100\%)

$\begin{array}{lllllll}9 & \text { III\&V } & 1: 2 & 22.58 & -6.45 & -70.97 & 0.55\end{array}$

\section{Pitta-Kaphaghni}

Rasa:Tikta (63\%) Katu (33\%)

Veerya:Ushna (100\%)

Vipaka:Katu (100\%)

\section{Pitta-Kaphaghni}

Rasa:Tikta (63\%) Katu (33\%)

Veerya:Ushna (100\%)

Vipaka:Katu (67\%) 
bleeding piles or Ardra arsas can be classified to Rakta-Pitta or Pitta-Kapha in nature and the external hemorrhoids or non-bleeding piles or Suska arsas can be classified to Vata-Kapha Arsas in nature ${ }^{5}$.

Hemorrhoids treatment- Ayurvedic concept: In a nutshell for Ardra arsas sodhanam, samanam, rakta stambhanam, rakta arsas cikitsa and adhogata rakta pitta cikitsa can be adopted. Similarly for Suska arsas vata-kapha hara, usna, srotosodhanam and vatanulomanam can be advised. The sitz bath (hip bath) a form of hydrotherapy using hot and cold water, steam and ice to restore and maintain health is also advisable. The detailed descriptions are available in the classical literatures and are not the subject matters of this paper.

\section{MATERIALS AND METHOD}

In the Arsacikitsita chapter of Astanga Hrudaya a famous classical formulation marketed by various manufacturers under the name of Dusparsakadi Kwatha is mentioned for treating the pain of hemorrhoids ${ }^{6}$. The traditional practitioners were prescribing the formulation by suitably altering the ingredients after keenly observing the conditions of Cikitsapurusha the patient under treatment and the degree of ailments. They even avoided the Dusparsaka that contribute to the name of the Kwatha/Kashaya as per modern manufacturers from the formulation while practicing by strictly adhering to the Texts. In most cases they prepare the Kwatha without Nagara while treating the bleeding piles $^{7}$. This yoga or formulation is also found as such in Caraka samhita in respective chapter dealing with Arsa roga ${ }^{8}$. The yoga or formulation is better known as Pathadi yoga by giving importance to the main ingredient. The individual components may vary as we observe the preparations and practices of Northern and Southern India. The Fagonia arabica is taken as Dusparsaka(I) in North and Tragia involucrate in Kerala while the Vilva(II) is Aegle marmelos all over India. The Apium graveolens(AyamodakamNorth) or Trachyspermum ammi (Ayamodakam) or Cuminum cyminum(Jeerakam) may be taken as Yavani(III) while Zingiber officinalis is Nagara(IV) all over India. The Cissampelos pareira is considered as Patha(V) in North India while Cyclea peltata is taken in Kerala. In this context the formulation mentioned in the classical texts was critically analyzed and computed their efficacies theoretically. The computed Drug Efficacy Indices $\left[Q_{(\mathrm{VPK})}\right]$ were tabulated and their numerical value along with other properties were found helpful to explain therapeutic values.

\section{EXPERIMENTAL}

The kwatha yoga or formulation marketed in the name of Dusparsakadi Kwatha citing the Astanga Hrudaya was critically analyzed to extract the real meaning by applying the Anusaraka concept ${ }^{9}$. For the same various available literatures on the formulation were collected and critically studied without any prejudice. The rasa-guna-veeryavipaka of individual constituents were inputted scientifically and the Drug Efficacy Indices $\left[Q_{(\mathrm{VPK})}\right]$ for various possible combinations were computed using the earlier reported formula ${ }^{10}$. The various combinations were also classified theoretically to respective classes according to their computed pharmacological effects (Table 1). The ingredient ratio to be maintained was not observed in any classical verses of this yoga or formulation. The method of preparation in common parlance was found those individual four ingredients in equal quantities and the prime ingredient Patha to be equal to four times of the individual ingredient constituting the half of the entire formulation. Hence the ratio maintained for this formulation was concluded to be $(1: 1: 1: 1: 4)$ when all the five ingredients were taken for preparing this yoga. This was also scientific by following the modern equal a priory principle for the rest of the ingredients when the main ingredient is fixed as the half of the entire formulation. This is also the same method adopting in the yagas while distributing the purodasa in ancient times. This was also observed so in the most ancient epic Ramayana while distributing the payasa obtained as a result of the Putrakamesti yaga by the king Dasaratha to his wives. It is well known that the philosophical bases of Ayurveda are rooted to Vedas and hence we might get answers or hints to solve many unanswered problems if we keenly observe. The drug efficacy indices of the marketed formulation with five constituents in a fixed ratio $(1: 1: 1: 1: 4)$ and the five individual constituents were computed. Based on the computational results the formulations were also classified according to their respective pharmacological types (Table 1).

Similarly the drug efficacy indices $\left[Q_{(\mathrm{VPK})}\right]$ of the combination of each one of the constituents 
Table 3: The Drug Efficacy Indices $\left[\mathrm{Q}_{\mathrm{(VPK}}\right]$ of combination in which two constituents are mixed in a ratio (1:1:2) with patha.

\begin{tabular}{|c|c|c|c|c|c|c|c|}
\hline SI. No. & Content & Ratio & Qv & Qp & Qk & $\mathbf{Q}_{\text {(VPK) }}$ & Pharmacological Type and Properties \\
\hline 11 & I,II\&V & 1:1:2 & 26.44 & -27.88 & -45.67 & 0.47 & $\begin{array}{l}\text { Pitta-Kaphaghni } \\
\text { Rasa :Tikta }(90 \%) \\
\text { Veerya:Ushna }(75 \%) \\
\text { Vipaka:Katu }(100 \%)\end{array}$ \\
\hline 12 & $\|\|, I \| \& V$ & 1:1:2 & 21.51 & -10.47 & -68.02 & 0.57 & $\begin{array}{l}\text { Pitta-Kaphaghni } \\
\text { Rasa:Tikta (69\%) Katu (25\%) } \\
\text { Veerya:Ushna (100\%) } \\
\text { Vipaka:Katu }(100 \%)\end{array}$ \\
\hline 13 & IIIIV\&V & 1:1:2 & 12.88 & $\mid-13.64$ & -73.48 & 0.74 & $\begin{array}{l}\text { Pitta-Kaphaghni } \\
\text { Rasa:Tikta (69\%) Katu (25\%) } \\
\text { Veerya:Ushna (100\%) } \\
\text { Vipaka:Katu }(75 \%)\end{array}$ \\
\hline 14 & III,IV\&V & 1:1:2 & 15.25 & 1.69 & -83.05 & 0.66 & $\begin{array}{l}\text { Kaphaghni } \\
\text { Rasa:Tikta (48\%) Katu (50\%) } \\
\text { Veerya:Ushna (100\%) } \\
\text { Vipaka:Katu }(75 \%)\end{array}$ \\
\hline 15 & $\mathrm{I}, \mathrm{III} \& \mathrm{~V}$ & 1:1:2 & 29.47 & -20.00 & -50.53 & 0.41 & $\begin{array}{l}\text { Pitta-Kaphaghni } \\
\text { Rasa:Tikta (69\%) Katu (25\%) } \\
\text { Veerya:Ushna (75\%) } \\
\text { Vipaka:Katu }(100 \%)\end{array}$ \\
\hline 16 & $\mathrm{I}, \mathrm{IV} \& \mathrm{~V}$ & 1:1:2 & 24.00 & -25.33 & -50.67 & 0.52 & $\begin{array}{l}\text { Pitta-Kaphaghni } \\
\text { Rasa:Tikta (69\%) Katu (25\%) } \\
\text { Veerya:Ushna (75\%) } \\
\text { Vipaka:Katu }(75 \%), \text { Swadu(25\%) }\end{array}$ \\
\hline
\end{tabular}


with Patha in a fixed ratio (1:2) were computed and based on the computational results these formulations were also classified to respective pharmacological classes (Table 2).

The drug efficacy indices $\left[Q_{(\mathrm{VPK})}\right]$ of a combination of two constituents with Patha in a fixed ratio (1:1:2) were computed and the combinations were classified (Table 3).

The drug efficacy indices $\left[Q_{(\mathrm{VPK})}\right]$ of a combination of three constituents with Patha in a fixed ratio (1:1:1:3) were computed and those combinations were classified (Table 4).

The results of these combinations were discussed in detail in the concerned sections.

\section{RESULTS AND DISCUSSION}

The computed Drug Efficacy Indices of individual constituents were compared and the pharmacological activities on Doshas were found comparable with the allotted properties as per the classical texts. The Dusparsaka belongs to Doorvadigana according to Vagbhata and is Pittasamana in nature ${ }^{11}$. The computational studies showed it have a predominant pitta pacifying capacity. The Vilva or Bilva belongs to Varanadigana and has Kaphamedohara property in addition to the capability to lead to Mandagnitva ${ }^{12,13}$. It is well known that Pitta is Agni and anything that leads to mandagnitva might be due to decreasing Pitta. The computational studies showed that it have Kapha and Pitta pacifying capacity and classified to Pitta-Kaphaghni with more capacity to pacify Kapha. The Yavani belongs to Pippalyadigana and has a property to pacify Kapha and sulaghni in nature ${ }^{14}$. This was same observed from the computational studies. The Nagara also belongs to Pippalyadigana and has Vatahara property in addition to Kaphahara property ${ }^{15}$. The computational studies classified the Nagara to Vata-Kaphagni class. The Patha belongs to Mustadigana and Aragvadadigana according to Susruta and Vagbhata classifies it to Aragvadadigana and Patoladigana. For Susruta it is Sleshmavishapaha, Sleshmanishudana and Kandughna. According to Vagbhata it is Kaphahara and Dushtavranavishodhana and in addition it is also Kapha-Pittahara ${ }^{16}$. The concepts of Susruta and Vagbhata were found to be complementary and supportive to each other when we correlate further. The Visha belongs to Pitta nature more than Vata or Kapha. Hence the Sleshmavishapaha might be considered as Kapha-pittapaha. The computational studies also showed that Patha is Pitta-Kaphaghni in nature with predominant capacity to pacify Kapha. The Dusparsakadi Kwatha belongs to Pitta-Kaphaghni category can be effectively used to treat the related pains of Arsas or piles of Pitta-Kapha Doshik nature. The Ardra-Arsa or bleeding piles or the internal hemorrhoids is considered to be Pitta-Kapha-Arsa in nature as evident from its clinical diagnosis and as well as from various ancient texts. So this classical formulation namely Dusparsakadi Kwath belonging to Pitta-Kaphaghni is observed to be useful for treating bleeding piles. Among the individual combinations with a fixed ratio (1:2) the combination 10 (Nagara and Patha) showed a very high Drug Efficacy Index $\left[Q_{(\mathrm{VPK})}\right]$ of 0.81 numerical value. Similarly among the various possible combinations of two constituents with Patha in a fixed ratio (1:1:2) the combination 13 (Vilva, Nagara and Patha) showed a very high Drug Efficacy Index $\left[Q_{(\mathrm{VPK})}\right]$ value of 0.74 . Of the various possible combinations of the three components with Patha in a fixed ratio (1:1:1:3) the combination 19 (Vilva, Yavani, Nagara and Patha) showed highest Drug Efficacy Index $\left[Q_{(\mathrm{VPK})}\right]$ value of 0.66 . It was observed that all these superior combinations contain Nagara as a component. Traditional practitioners many times avoid Nagara containing drugs while treating bleeding piles in a maximum possible manner ${ }^{17}$. The other combinations like 8, 9\& 12 without Nagara also showed higher Drug Efficacy Index $\left[Q_{(\mathrm{VPK})}\right]$ values than the marketed Dusparsakadi Kwatha and those combinations could be selected for handling such cases effectively.

\section{CONCLUSION}

The present study showed the application of computational studies to theoretically predict the efficacies of various combinations of Pathadi yoga or Dusparsakadi Kwatha yoga explained in the classical texts. The Drug Efficacy Index $\left[Q_{(\mathrm{VPK})}\right]$ values of individual components and various combinations of them were calculated and compared with the properties as mentioned in classical texts. The usual ratio of combination taken by the traditional practitioners can also be found scientifically explained with the present studies. The further computational studies are going on to explain scientifically how the 
Table 4: The Drug Efficacy Indices $\left[\mathrm{Q}_{\mathrm{(VPK}}\right]$ of formulations with a combination in which three constituents are mixed in a ratio (1:1:1:3) with patha.

\begin{tabular}{|c|c|c|c|c|c|c|c|}
\hline Sl. No. & Content & Ratio & Qv & Qp & Qk & $\mathbf{Q}_{(\mathrm{VPK})}$ & Pharmacological Type and Properties \\
\hline 17 & I,II,III\&V & $1: 1: 1: 3$ & 25.96 & -20.00 & -54.04 & 0.48 & $\begin{array}{l}\text { Pitta-Kaphaghni } \\
\text { Rasa :Tikta }(76 \%), \text { Katu(17\%) } \\
\text { Veerya:Ushna }(83 \%) \\
\text { Vipaka:Katu }(100 \%)\end{array}$ \\
\hline 18 & I,II,IV\&V & $1: 1: 1: 3$ & 22.04 & -23.27 & -54.69 & 0.56 & $\begin{array}{l}\text { Pitta-Kaphaghni } \\
\text { Rasa:Tikta (76\%) Katu (17\%) } \\
\text { Veerya:Ushna (83\%) } \\
\text { Vipaka:Katu (83\%) }\end{array}$ \\
\hline 19 & II,III,IV\&V & $1: 1: 1: 3$ & 17.22 & -8.13 & -74.64 & 0.66 & $\begin{array}{l}\text { Pitta-Kaphaghni } \\
\text { Rasa:Tikta (62\%), Katu (33\%) } \\
\text { Veerya:Ushna (100\%) } \\
\text { Vipaka:Swadu (83\%) }\end{array}$ \\
\hline 20 & I,III,IV\&V & $1: 1: 1: 3$ & 24.23 & -16.30 & -59.47 & 0.52 & $\begin{array}{l}\text { Pitta-Kaphaghni } \\
\text { Rasa:Tikta (62\%), Katu (33\%) } \\
\text { Veerya:Ushna (83\%) } \\
\text { Vipaka:Swadu (83\%) }\end{array}$ \\
\hline
\end{tabular}


ratios found in common parlance were fixed by the ancient scientists for preparing various formulations in addition to introduce a new software for predicting the efficacies of various combinations.

\section{AUTHOR DISCLOSURE STATEMENT}

There is no conflict of interest.

\section{REFERENCES}

1. Abhilash Mullasseril. Fluorescence Classification of Microbes An Ayurvedic Perspective. Ayurvedic Renaissance. 2013; 11(2): 3-5.

2. Abhilash Mullasseril. Drug Designing An Ayurvedic Perspective. IOSR Journal of Pharmacy. 2013; 3(4): 29-33.

3. Warrier AGK. Srimad Bhagavad Gita Bhasya of Sri Samkaracarya. $1^{\text {st }}$ ed. Mylapore, Chennai: Sri Ramakrishna Math; 2002: 62-63.

4. Sarma U. Arsaroganidana. In: Sastri BS, ed. Madhavanidana of Srimadhavakara with Sudhalahari Comments. Benares: Chowkhamba Sanskrit Series; 1943: 40-46.

5. Srinivasulu M. Clinical Diagnosis in Ayurve$\mathrm{da}$ [A Practical Book of Ayurvedic Diagnosis in the Light of Modern Medical Science ]. $1^{\text {st }}$ ed. Delhi: Choukhamba Sanskrit Pratishthan; 2011: 452-453.

6. Kunte AM, Shastri KR. Arsacikitsitadhyaya. In: Sastri HP. ed. Astangahrdayam (A compendium of the Ayurvedic System) Composed by Vagbhata with commentaries Sarvangasundara of Arunadatta and Ayurvedarasayana of Hemadri. Varanasi: Chowkhamba Krishnadas Academy; 2009: 648.

7. Mahadevan L, Khan A, Gayathri R. Critical Analysis of Ayurvedic Formulations (Sahasrayoga and Other Samhitas). $1^{\text {st }}$ ed. Derisanamcope: Sarada Mahadeva lyer Ayurvedic Educational \& Charitable Trust; 2014: 192.

8. Cakrapanidatta. Arsacikitsitam. In: Acharya JT. ed. Caraka Samhita by Agnivesa Revised by Caraka and Drdhabala with Ayurveda Dipika commentary. Varanasi: Chowkhamba Krishnadas Academy; 2010: 506.

9. Akshar Bharati, Chaitanya V, Sangal R. Natural Language Processing A Paninian Perspective. $1^{\text {st }}$ ed. New Delhi: Prentice Hall of India Pvt. Ltd.; 1999.

10. Abhilash Mullasseril. The Drug Efficacy In$\operatorname{dex}\left[Q_{(\mathrm{VPK})}\right]$ A Novel Parameter To Calculate
Theoretically The Efficacy And Efficiency Of Ayurvedic Formulations. Journal of Bioprocessing and Chemical Engineering. 2015; 3(1): 1-5.

11. Kunte AM, Shastri KR. Sodhanadiganasangraha. In: Sastri HP. ed. Astangahrdayam (A compendium of the Ayurvedic System) Composed by Vagbhata with commentaries Sarvangasundara of Arunadatta and Ayurvedarasayana of Hemadri. Varanasi: Chowkhamba Krishnadas Academy; 2009: 232.

12. Kunte AM, Shastri KR. Sodhanadiganasangraha. In: Sastri HP. ed. Astangahrdayam (A compendium of the Ayurvedic System) Composed by Vagbhata with commentaries Sarvangasundara of Arunadatta and Ayurvedarasayana of Hemadri. Varanasi: Chowkhamba Krishnadas Academy; 2009: 236.

13. Dalhanacarya. Dravyasamgrahaneeyamadhyaya. In: Acarya JT. Ed. Susruta Samhita of Susruta with the Nibandhasangraha Commentary. Varanasi: Chowkhamba Krishnadas Academy; 2008:164-165.

14. Dalhanacarya. Dravyasamgrahaneeyamadhyaya. In: Acarya JT. Ed. Susruta Samhita of Susruta with the Nibandhasangraha Commentary. Varanasi: Chowkhamba Krishnadas Academy; 2008:166.

15. Kunte AM, Shastri KR. Annaswaroopavijnaneeya. In: Sastri HP. ed. Astangahrdayam (A compendium of the Ayurvedic System) Composed by Vagbhata with commentaries Sarvangasundara of Arunadatta and Ayurvedarasayana of Hemadri. Varanasi: Chowkhamba Krishnadas Academy; 2009: 119.

16. Dalhanacarya. Dravyasamgrahaneeyamadhyaya. In: Acarya JT. Ed. Susruta Samhita of Susruta with the Nibandhasangraha Commentary. Varanasi: Chowkhamba Krishnadas Academy; 2008:164.

17. Mahadevan L. Ayurvedic Clinical Practice volume-1. 2nd ed. Derisanamcope: Sarada Mahadeva lyer Ayurvedic Educational \& Charitable Trust; 2014: 79-86

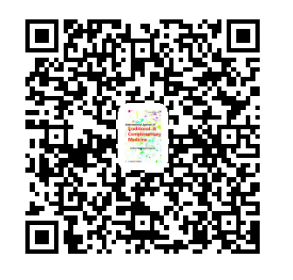

